\title{
Implication of cholinergic transmission in rat model of spinal cord injury: A potential therapeutic target
}

\author{
Hongzhe Liu, Lei Chang, Shuai Peng, Bin Liu, Mingyan Zhang, Xiangyang Liu* \\ Department of Spine Surgery, The People's Hospital of Hunan Province, Changsha, Hunan 410005, China \\ *For correspondence: Email: xiangyangliu35@hotmail.com; Tel: 0086-0731-84762686
}

Sent for review: 20 August 2018

Revised accepted: 16 March 2019

\begin{abstract}
Purpose: To assess the involvement of cholinergic transmission in the etiology of spinal cord injury (SCl) in a rat model.

Methods: Male adult rats (Wistar) with body weight ranging from 200 to $250 \mathrm{~g}$ were equally allocated into 2 groups: test (SCl) and control (non-SCl). Clipping method was used to induce SCl. Thereafter, motor function was measured using rotarod. Each rat was sacrificed by decapitation, and the cortex was excised for use in the study of the involvement of cholinergic transmission in SCI using real time quantitative polymerase chain reaction (RT-PCR) and western blot analysis (WBA).

Results: Significant upregulation in acetylcholine esterase (AChE) was observed in the cortex of SCI rats, relative to non-SCl rats $(p<0.005)$. Results from cholinergic receptor binding studies revealed significantly decreased maximum binding (Bmax) and dissociation constant $(k d)$ values for muscarinic receptors in $\mathrm{SCl}$ rats, when compared to non-SCl rats. Moreover, the reduction in intensity of cholinergic receptors was significantly greater in the cerebral cortex of SCI group compared to non-SCI group.

Conclusion: The results of this study suggested that the reduction in cortical cholinergic transmission impairs motor functions in SCl, and plays a major role in motor deficits in SCl.
\end{abstract}

Keywords: Spinal cord injury, Cholinergic receptor, Acetylcholine esterase, Nicotinic receptor, Muscarinic receptor

\begin{abstract}
This is an Open Access article that uses a fund-ing model which does not charge readers or their institutions for access and distributed under the terms of the Creative Commons Attribution License (http://creativecommons.org/licenses/by/4.0) and the Budapest Open Access Initiative (http://www.budapestopenaccessinitiative.org/read), which permit unrestricted use, distribution, and reproduction in any medium, provided the original work is properly credited.

Tropical Journal of Pharmaceutical Research is indexed by Science Citation Index (SciSearch), Scopus, International Pharmaceutical Abstract, Chemical Abstracts, Embase, Index Copernicus, EBSCO, African Index Medicus, JournalSeek, Journal Citation Reports/Science Edition, Directory of Open Access Journals (DOAJ), African Journal Online, Bioline International, Open-J-Gate and Pharmacy Abstracts
\end{abstract}

\section{INTRODUCTION}

Spinal cord injury $(\mathrm{SCl})$ is one of the leading causes of severe incapacitation associated with high health care expenses [1,2]. Globally, SCI affects more than 2 million individuals [2]. Understanding CNS pathways after $\mathrm{SCl}$ is key to establishing an accurate treatment for the disease [1]. During $\mathrm{SCl}$, changes at neurotransmitter levels in motor cortex are helpful for the accurate understanding of brainspinal cortex synchronization. Studies have reported the participation of several cortical areas in the control of motor function in individuals with stroke during the recovery period [1-4]. However, majority of these studies have failed to show accurate mechanism of recovery in the stroke patients. Thus, understanding the effect of neurotransmitter adaptations in cortex could help in recognizing its role in controlling 
motor functions [5-8].

The acetylcholine released from cortex has several functional roles, one of which is regulation of motor function. The roles of cholinergic receptors in regulating spinal cord functions are well-known [9-12]. The muscarinic receptors in CNS regulate learning and memory, and are also involved in controlling several sensory, motor, and autonomic routes. Muscarinic acetylcholine receptor plays a vital role in the functioning of sensory and motor structures [3]. Acetylcholine is produced through acetyltransferase. In neurons, acetylcholine is transferred into synaptic vesicles using acetylcholine transporter. It is then hydrolyzed by acetylcholinesterase, resulting in execution of specific pharmacological actions. Several studies have reported the use of choline acetyltransferase as potential bio-marker for assessing the status of cholinergic conduction, where it serves as indicator for the functional activity of cholinergic innervations [1315]. Currently, very little is known about the involvement of cholinergic transmission in rat model of motor deficits. Thus, the current study was intended to evaluate the position of the cholinergic pathway in $\mathrm{SCl}$.

\section{EXPERIMENTAL}

\section{Animals}

Male adult rats (Wistar) having body weight from 200 to 250 gram were kept in isolated cages with 12-h day/12-h night cycle, with ad libitum access to rat feed and drinking water. The study protocol of this experiment was approved by Animal Ethics Committee of the Hunan Academy of Medical Sciences and Hunan Provincial People's Hospital, China (approval no. AEC$\mathrm{HPPH} / 238 / 2018$ ), and followed the principle laid down in the Association for Assessment and Accreditation of Laboratory Animal Care International (AAALAC) and National Research Council's Guide for the Care and Use of Laboratory Animals [16]. The rats were equally allocated in 2 groups: test (SCl) and control (non$\mathrm{SCl}$ ). Chronic $\mathrm{SCl}$ was induced using the clipping method. Each rat was sacrificed by decapitation, and the cortex was dissected and stored at -80 ${ }^{\circ} \mathrm{C}$ prior to assays.

\section{Motor function assessment using rotarod test}

Following the induction of $\mathrm{SCl}$. the motor function of the rats was tested using rotarod test. In this test, each rat was trained 5 times before taking actual reading to assess its motor function. The actual reading was recorded for each rat at different speeds (rpm): low (10 rpm), medium 15 $\mathrm{rpm}$, and high/fast (25). In addition, retention time was measured at these rpm values in both groups.

\section{RT-PCR and Western blot assay (WBA)}

Real-time PCR assay was conducted in 96-well kits in a PCR instrument. The PCR assay was performed with the primers for AChE, ChAT, M1 receptor, M3 and nicotinic receptor, with RT$\beta$-actin as internal control. Total protein (approx. $50 \mu \mathrm{g}$ ) was extracted from cells or tissues of cortex and fractionated using $10 \%$ SDSpolyacrylamide gel electrophoresis. The bands were then transferred to nitrocellulose membrane, and images were captured using Odyssey Infrared Imaging System. The loading control was glyceraldehyde 3-phosphate dehydrogenase (GAPDH).

\section{Immunohistochemistry}

Dissected cortex was immersed in phosphate buffer $(\mathrm{pH}$ 7.4) and $4 \%$ paraformaldehyde solution for $60 \mathrm{~min}$ and then put in sucrose solution (30\%). After $1 \mathrm{~h}$, the cortex was sliced into different sections using cryostat. Each section of cerebral cortex was treated with phosphate buffer at $\mathrm{pH} 7.4$ for half an hour, and then incubated with muscarinic or nicotinic acetylcholine receptor antibody. Images of cerebral cortex sections were taken using confocal imaging method. The expressions of muscarinic and nicotinic acetylcholine receptors were evaluated using pixel intensity technique.

\section{Receptor-binding assays}

Receptor-binding was determined using Scatchard method for assessment of receptor binding variables such as $B_{\max }$ (maximum binding), and $k_{d}$ (dissociation constant). Usually, $B_{\max }$ is used to measure expression of receptors available in cortex sample, while $k_{d}$ is an index of the affinity of the muscarinic and nicotinic receptors for ligands.

\section{Statistical analysis}

Statistical analysis of data was performed using SPSS statistical analysis software. Comparison of retention times and the expressions of muscarinic and nicotinic receptors in cortical region between both groups $(\mathrm{SCl}$ and non-SCl) were analyzed by $t$-test. Data related to muscarinic receptor binding analysis in cortex for both groups were analyzed using non-parametric test (Mann Whitney test). Pixel intensities in the 
cortex between both groups were analyzed by non-parametric test.

\section{RESULTS}

\section{Rotarod results}

In the rotarod test, significantly lower retention time was observed in $\mathrm{SCl}$ rats than in the non$\mathrm{SCl}$ rats at all rotations $(10,15$ and $25 \mathrm{rpm})(p=$ 0.003; Figure 1).

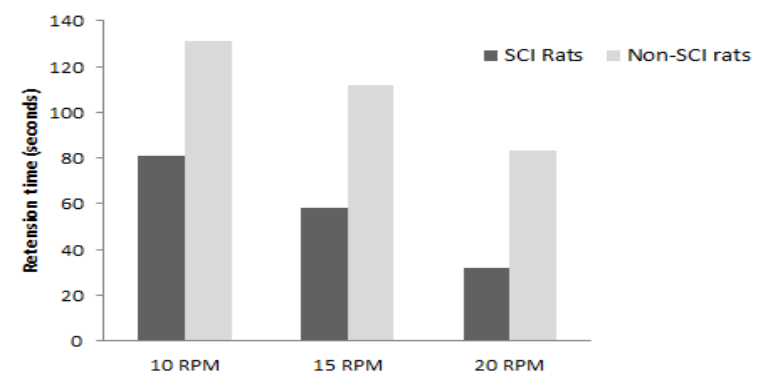

Figure 1: Comparison of retention times (seconds) after rotarod test in rats with and without $\mathrm{SCl}$; ${ }^{*} p<$ 0.001 , compared to rat without $\mathrm{SCl}$

\section{Expressions of AChE and choline AchE}

Results from RT-PCR assay revealed that the expressions of $\mathrm{AChE}$ and choline AChE were significantly greater in $\mathrm{SCl}$ group compared to non- $\mathrm{SCl}$ group. Western blot analysis showed significantly higher upregulation of AChE in the cortex region of $\mathrm{SCl}$ group as compared to non$\mathrm{SCl}$ group (Figure 2).

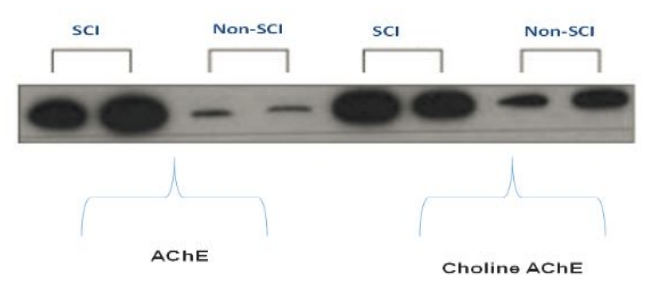

Figure 2: Western blot analysis showing the expressions of AChE and choline AChE in cortex regions of $\mathrm{SCl}$ and non-SCl rats

\section{Expressions of muscarinic and nicotinic acetylcholine receptors}

Receptor binding analysis using pixel intensity showed that the expressions of muscarinic and nicotinic acetylcholine receptors were significantly decreased in $\mathrm{SCl}$ rats, when compared to non-SCl rats (Figure 3).

\section{Muscarinic receptor binding}

Muscarinic receptor binding analysis in the cortex regions of $\mathrm{SCl}$ and non-SCl rats showed that
$\mathrm{B}_{\max }$ and $\mathrm{k}_{\mathrm{d}}$ values for muscarinic receptor type 1 (MRT1), MRT3 and total MR were significantly lower in $\mathrm{SCl}$ group as compared to non-SCl group. Results are shown in Table 1.

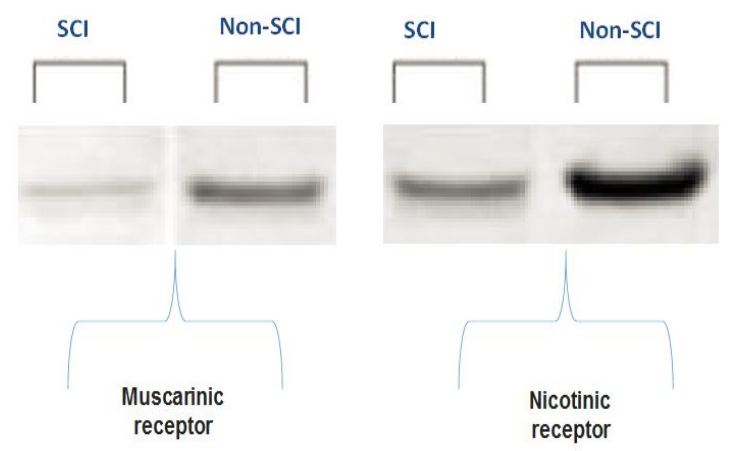

Figure 3: Western blot analysis showing the expressions of muscarinic and nicotinic receptors in cortical regions of $\mathrm{SCl}$ and non-SCl rats

Table 1: Muscarinic receptor binding analysis showing $B_{\max }$ and $k_{d}$ for MRT1, MRT3 and total MR in the cortex region

\begin{tabular}{|c|c|c|}
\hline Variable & $\begin{array}{l}\text { SCI rats } \\
(n=20)\end{array}$ & $\begin{array}{l}\text { Non-SCI } \\
\text { rats } \\
(n=20)\end{array}$ \\
\hline \multicolumn{3}{|l|}{$\begin{array}{l}\text { Muscarinic receptor } \\
\text { (total)* }\end{array}$} \\
\hline$B_{\max }$ & \multirow{3}{*}{$113.1 \pm 3.10$} & \multirow{3}{*}{$\begin{array}{l}221.1 \pm \\
13.10\end{array}$} \\
\hline (fmoles & & \\
\hline $\begin{array}{l}\text { per mg } \\
\text { protein) }\end{array}$ & & \\
\hline$(n M)^{k_{d}}$ & $0.41 \pm 0.21$ & $2.41 \pm 0.01$ \\
\hline \multicolumn{3}{|c|}{ Muscarinic receptor type 1 (MRT1)* } \\
\hline$B_{\max }$ & $123.4 \pm 11.70$ & \multirow{3}{*}{$\begin{array}{l}253.2 \pm \\
18.5 \\
8.87 \pm 0.13\end{array}$} \\
\hline$k_{d}$ & $3.17 \pm 0.33$ & \\
\hline \multicolumn{2}{|c|}{ Muscarinic receptor type 3 (MRT3)* } & \\
\hline$B_{\max }$ & $124.1 \pm 15.70$ & $241.1 \pm 15.7$ \\
\hline$k_{d}$ & $1.31 \pm 0.92$ & $4.61 \pm 0.81$ \\
\hline
\end{tabular}

Data are presented as mean \pm SD. $n$ : total number of subjects; ${ }^{*} p<0.001$

\section{Pixel intensity}

There was significantly greater reduction of pixel intensity (mean) in cortex region of $\mathrm{SCl}$ rats, relative to non-SCI rats (Table 2 ). This indicates reduced intensity of cholinergic receptors in cortex region of $\mathrm{SCl}$ rats. A similar trend in low pixel intensity was observed in the assessment of nicotinic receptors in the cortex region of $\mathrm{SCl}$ rats. Pixel intensity was significantly reduced in $\mathrm{SCl}$ rats, when compared to non-SCl rats. The cumulative results of both receptors indicated decreased activities of nicotinic and muscarinic receptors in cortex region of $\mathrm{SCl}$ rats when compared to non-SCl group. 
Table 2: Pixel intensity in cortex of $\mathrm{SCl}$ and non-SCl rats

\begin{tabular}{lll}
\hline Variable & $\begin{array}{l}\text { Rats with } \\
\mathbf{S C l} \\
(\mathbf{n = 2 0 )}\end{array}$ & $\begin{array}{l}\text { Non-SCI rats } \\
(\mathbf{n = 2 0 )}\end{array}$ \\
\hline $\begin{array}{l}\text { Muscarinic receptor } \\
\text { (MRT1) }\end{array}$ & $28.13 \pm 3.14$ & $67.18 \pm 4.14$ \\
$\begin{array}{l}\text { Nicotinic receptor } \\
(\text { alpha 7) }\end{array}$ & $32.19 \pm 2.15$ & $84.43 \pm 8.35$ \\
\hline $\begin{array}{l}\text { Data are presented as mean } \pm \text { SD. n: total number of } \\
\text { subjects; }{ }^{*} p<0.001\end{array}$
\end{tabular}

\section{DISCUSSION}

The results of current study showed that there was significant decrease in activity of cholinergic receptors, which led to reduction in motor function associated with the cholinergic receptor or neurotransmitter in $\mathrm{SCl}$. Cholinergic receptor function was impaired in the $\mathrm{SCl}$ rats. In addition, it was observed that the activity of AChE, the enzyme activity which regulates cholinergic transmission, was significantly impaired in $\mathrm{SCl}$ rats, when compared with non-SCl rats. This indicates reduced intensity of cholinergic receptors in cortex region of $\mathrm{SCl}$ rats, relative to non-SCl rats. Low pixel intensities were observed for cholinergic receptors in cortex region of $\mathrm{SCl}$ rats.

The results of the present study suggest a metabolic impairment in cholinergic system of CNS. In addition, a gene expression of acetylcholine esterase was significantly higher in the cortex region of $\mathrm{SCl}$ rats. This resulted in accentuated degradation of acetylcholine which also controls motor functions, and hence impaired cholinergic transmission in $\mathrm{SCl}$. In SCl, increased expression of acetylcholine esterase results in low levels of acetylcholine, which further reduces motor functions. Increased expression of acetylcholine esterase has been observed in Alzheimer disease, a neurodegenerative disorder [17-19]. Defects in motor function in $\mathrm{SCl}$ are possibly due to impaired transmission of cholinergic pathways.

The role of cholinergic receptors (nicotinic and muscarinic receptors) in regulating spinal cord functions have been previously reported [13$15,17,18]$. Muscarinic receptors in CNS are associated with the regulation of learning and memory, and are also involved in controlling several sensory, motor, and autonomic routes. Muscarinic receptor of acetylcholine plays a vital role in functioning of sensory and motor structures [3]. The expressions of several receptors in nociceptive pathway are changed in the dorsal horn region of spinal cord after peripheral nerve injury. In this situation, the stimulation of nicotinic receptor of acetylcholine stimulates survival of spinal motor neurons [19]. These results indicate that impairment of cholinergic transmission acts as one of key contributors to motor deficits in SCl. Thus, cholinergic system may be a useful target for an effective treatment option for motor deficits associated with $\mathrm{SCl}$.

\section{CONCLUSION}

This study demonstrates that impairment of cholinergic transmission via cholinergic receptors (muscarinic and nicotinic) may result in development of $\mathrm{SCl}$ in rats. The reduction in cholinergic transmission in the cortex impairs motor function and plays a major role in motor deficits in SCl. Thus, the targeting of the cholinergic system may help to find effective treatment for motor deficits in $\mathrm{SCl}$.

\section{DECLARATIONS}

\section{Conflict of Interest}

No conflict of interest associated with this work.

\section{Contribution of Authors}

We declare that this work was done by the authors named in this article and all liabilities pertaining to claims relating to the content of this article will be borne by the authors. All authors involved in design of study, data acquisition, analysis and writing including revising the paper. All authors have read and approved the manuscript for publication.

\section{Open Access}

This is an Open Access article that uses a funding model which does not charge readers or their institutions for access and distributed under the terms of the Creative Commons Attribution License (http://creativecommons.org/licenses/by/ 4.0) and the Budapest Open Access Initiative (http://www.budapestopenaccessinitiative.org/rea d), which permit unrestricted use, distribution, and reproduction in any medium, provided the original work is properly credited.

\section{REFERENCES}

1. Dong Y, Dobkin BH, Cen SY, Wu AD, Winstein CJ. Motor cortex activation during treatment may predict therapeutic gains in paretic hand function after stroke. Stroke 2006; 37: 1552-1555. 
2. Patrick F, Armin C, Karl F, Alan T. Tracking Changes following Spinal Cord Injury Insights from Neuroimaging. Neuroscientist 2013; 19: 116-128.

3. James K, Wamsley MS, Lewis W, Scott Y, Michael JK Autoradiographic localization of muscarinic cholinergic receptors in rat brainstem. J Neurosci 1981; 1: 176-191.

4. Jiang $H$, Zhang J, Zhu H, Li H, Zhang $X$. Nerve growth factor prevents the apoptosis-associated increase in acetylcholinesterase activity after hydrogen peroxide treatment by activating AktActa Biochim Biophys Sin 2007;39: 46-56.

5. Kuhar MJ, Murrin LC. Sodium-dependent, high affinity choline uptake. J Neurochem 1978; 30: 15-21.

6. Kus L, Borys E, Ping Chu Y, Ferguson SM, Blakely RD, Emborg ME, Kordower JH. Distribution of high affinity choline transporter immunoreactivity in the primate central nervous system. J Comp Neurol 2003; 463: 341 357.

7. Levine RR, Birdsall NJM. Pronounced pharmacologic deficits in M2 muscarinic acetylcholine receptor knockout mice. Life Sci 1997; 60: 963-1207

8. Lotze M, Markert J, Sauseng P, Hoppe J, Plewnia C, Gerloff $C$. The role of multiple contralesional motor areas for complex hand movements after internal capsular lesion. J Neurosci 2006; 26: 6096-6102.

9. Messi ML, Renganathan M, Grigorenko E, Delbono O. Activation of $\alpha 7$ nicotinic acetylcholine receptor promotes survival of spinal cord motoneurons. FEBS Lett 1997; 411: 32-38.

10. Mooradian AD. Effect of aging on the blood-brain barrier. Neurobiol Aging 1988; 9: 31-39.

11. Myers CP, Lewcock JW, Hanson MG, Gosgnach $S$, Aimone JB, Gage FG, Lee KF. Cholinergic input is required during embryonic development to mediate proper assembly of spinal locomotor circuits. Neuron 2005; 46: 37-49.

12. Marc D, Girard M, Van der Werf S. A Gly1 to Ala substitution in poliovirus capsid protein VPO blocks its myristoylation and prevents viral assembly. J Gen Virol 1991;72: 1151-1157

13. Saltarelli $M D$, Lowenstein PR, Coyle JT. Rapid in vitro modulation of $[3 \mathrm{H}]$ hemicholinium-3 binding sites in rat striatal slices. Eur J Pharmacol 1987; 135: 35-40.

14. Scatchard G. The attractions of proteins for small molecules and ions. Ann N Y Acad Sci 1949; 51: 660672.

15. Ward NS, Brown MM, Thompson AJ, Frackowiak RS. Neural correlates of motor recovery after stroke: a longitudinal fMRI study. Brain 2003; 126: 2476-2496.

16. Guide for the Care and Use of Laboratory Animals: Eighth Edition [Internet]. Committee for the Update of the Guide for the Care and Use of Laboratory Animals; National Research Council [cited 2019 Feb 2]. Available from: https://grants.nih.gov/grants/olaw/guide-for-thecare-and-use-of-laboratory-animals.pdf

17. Wessler I, Kirkpatrick CJ. Acetylcholine beyond neurons: the non-neuronal cholinergic system in humans. $\mathrm{Br} \mathrm{J}$ Pharmacol 2008; 154: 1558-1571.

18. Yamamura HI, Synder G. Muscarinic cholinergic binding in rat brain. Proc Natl Acad Sci USA 1974; 71: 17251729.

19. Zaninetti $M$, Tribollet $E$, Bertrand $D$, Raggenbass $M$. Presence of functional neuronal nicotinic acetylcholine receptors in brainstem motoneurons of the rat. Eur $J$ Neurosci 1999; 11: 2737-2748. 